\title{
Madeleine Herren
}

\section{"Very old Chinese bells, a large num- ber of which were melted down." Art, Trade, and Materiality in the Global Transformations of Japanese Bells}

\begin{abstract}
In the second half of the $19^{\text {th }}$ century, Buddhist bells from Japan began to arrive in Switzerland. The fact that these were objects listed in the so-called ethnographic collections is not surprising and the history of collecting has been a subject of postcolonial research. However, remarkably, the travel route of these bells, some of which weighed over a ton, could not be documented. Until now, the way how the bells were imported into Switzerland was unknown, and the problem of their provenance unsolved. This article argues that a global history approach provides new insights in two respects: The consideration of materiality allows a new understanding of the objects, while the activities of local collectors, seen from a micro-global point of view, reveal the local imprints of the global. Within this rationale, a history of individual bells in the possession of individual art lovers and museums translates into a history of scrap metal trade, allows to consider the disposal of disliked objects at their place of origin, and opens up a global framing of local history. Using global history as a concept, the historicity of the global gains visibility as we look at the intersection of materiality and the local involvement of global networks. Ultimately, as we follow the journey of the bells, reinterpreting scrap metal into art has formed a striking way in which local history assimilates the global.
\end{abstract}

Key Words: Global history, Switzerland $19^{\text {th }}$ century, Japan $19^{\text {th }}$ century, Buddhist bells, bronze trade.

Madeleine Herren is professor of history and director of the Institute for European Global Studies at the University of Basel, Switzerland. She has written multiple books, book chapters and journal articles on European and global history of the $19^{\text {th }}$ and $20^{\text {th }}$ centuries, internationalism and the history of international organizations, networks in historical perspective, historiography and intellectual history. Her publications include 'Gender and international relations through the lens of the League of Nations' in G. Sluga, C. Janes (eds.) Women, Diplomacy and International Politics since 1500 (2016), Transnational History, Theories, Methods, Sources, co-authored with M. Rüesch and C. Sibille (2012), and Internationale Organisationen seit 1865. Eine Globalgeschichte 
der internationalen Ordnung (2009). Her most recent publications include 'Strength through Diversity? The Paradox of Extraterritoriality and the History of the Odd Ones Out', Journal of the History of International Law 22 (2020), (https://doi.org/10.1163/15718050-12340153), and co-authored with Susanna Burghartz Building Paradise, a Basel Manor House and Its Residents in a Global Perspective (forthcoming 2021).

\section{Introduction}

In the late $19^{\text {th }}$ century, the Geneva-based art collector Gustave-Philippe Revilliod added to his considerable collection of East Asian Art a Japanese temple bell, an old and fine work from the $17^{\text {th }}$ century. The massive bronze bell sat with its heavy weight of almost a ton in the Ariana Park at the shore of Lake Geneva for almost half of a century, until the moment a member of the Japanese League of Nations' delegation rediscovered the bell as Japanese heritage after World War I. In 1930, shortly before the world fell apart, Revilliod's heir, the city and Canton of Geneva, gave the bell back to its spiritual owner, the Buddhist temple, who organized the bell's serene return to Tokyo. This event was orchestrated with extended media coverage presenting both an active Swiss multilateralism and an East Asian great power, adding globality to the transcultural fabric of Geneva. In the 1990s the history of the bell once again attracted the attention of the public, when the temple offered to the Canton of Geneva a replica, which now also resides at the Ariana Park, today literally the focal point of global internationalism, sharing the space with the building of the United Nations and the ICRC. ${ }^{1}$ Since the bell survived the war undestroyed and was neither contaminated by colonial looting nor misused as prey of war, the object obviously offers a consolidating message: Globality offers a material consistency, and objects made from a substance which is detached from the temporal limits of human lives almost confirms the existence of transboundary exchange even beyond the conceptional weaknesses of international relations. With the increasing importance of global history in both in its theoretical and its

1 For today's interest in the bell, its presentation and journey see “The Park,” Ariana Musée de la Céramique et du Verre, accessed April 26, 2021, http://institutions.ville-geneve.ch/en/ariana/discover/history/the-park/. Additional information is available from "Historique de La Cloche," Association d'amitié Genève-Shinagawa, accessed April 26, 2021, http://www. geneve-shinagawa.ch/cloche.html, for the exchange of the bell and its legal background see Raphael Contel, Anne Laure Bandle, and Marc-André Renold, "Affaire Cloche de Shinagawa - Ville de Genève et Temple de Shinagawa," Plateforme ArThemis (http://unige.ch/art-adr), Centre du droit de l'art, Université de Genève, accessed April 26, 2021, https://plone. unige.ch/art-adr/cases-affaires/cloche-de-shinagawa-2013-ville-de-geneve-et-japon. 
methodological aspects, ${ }^{2}$ the materiality-based past of the bell gives us reason to look more closely and to unravel new findings, although not without the acceptance of some uneasy insights:

First of all, the historicity of the Shinagawa bell is paradoxically based on ignorance. Both Japanese diplomatic correspondence and contemporary art history literature agrees that the bell's place of origin is well known, but its route to Europe remains obscure. ${ }^{3}$ Although there is much speculation as to whether the bell was originally part of the World's fair in Paris in 1867 or in Vienna in 1873 and came to Europe as exhibit, neither those who sent the bell on its way nor those who received and bought it are known or even addressed in this narrative. ${ }^{4} \mathrm{~A}$ comparable uncertainty characterizes the reasons why a centuries-old temple bell had to leave its traditional location: On one hand, a fire in the temple is mentioned as a possible explanation for the expatriation of the bell, on the other hand, the power shift to the Meiji regime explains the disempowerment of Buddhist monasteries in the second half of the $19^{\text {th }}$ century. The inconsistency in the explanation and the gaps in knowledge are both remarkable, since we are not dealing with a delicate painting, a featherweight silk textile or a small statuette, but with a bronze object weighing more than a ton. Usually, an object of this size leaves its marks in the form of documents, if only because bronze has a considerable commodity value, which in the $19^{\text {th }}$ century did not pass the many customs borders unnoticed. However, such a documentation could not be found until now. The lack of a paper trail may have many reasons - documents are lost, destroyed or simply forgotten. In this article, however, we assume that the established historiographical research methods will fail to find an answer in the case presented. We therefore presume that such a paper trail never existed, because the global journey transformed the object in a way that its specification as a bell literally disappeared. This assumption challenges central elements of global history, contributing to the ongoing debate about material culture and its connection to micro-global history. ${ }^{5}$ With the example of the bell in mind (and remaining aware of the limits of this example), this contribution suggests reflecting on a different theoretical setting. This approach recommends

2 For the debate on micro-global history and material culture see Anne Gerritsen and Giorgio Riello, eds., Writing Material Culture History, $2^{\text {nd }}$ ed. (London et. al.: Bloomsbury Academic, 2021); Anne Gerritsen and Giorgio Riello, eds., The Global Lives of Things. The Material Culture of Connections in the Early Modern World (London/New York: Routledge, 2016); Maxine Berg et. al., eds., Goods from the East, 1600 - 1800. Trading Eurasia, (London: Palgrave Macmillan, 2015).

3 JACAR (Japan Center for Asian Historical Records), Ref. B04012326800, Miscellaneous Documents Relating to Antiques and Treasures/ 8. Documents Relating to Great Bell of Buddhist Temple at Musee Ariana in Geneva (I-1-7-0-8) (Diplomatic Archives of the Ministry of Foreign Affairs) About the disappearance of the bell from archival documentation see Didier Grange, "Quand l'histoire rencontre la légende," in Genève-Shinagawa Shinagawa-Genève, ed. Eric Burkhard et al. (Geneva: Association d'amitié Genève-Shinagawa, 1996), 31-40.

4 F.C., “Cloche japonaise de l’Ariana," Bulletin de La Société Franco-Japonaise de Paris 71 (1930): 108 - 109, https://gallica. bnf.fr/ark:/12148/bpt6k9682009t.texteImage.

5 In our context of special interest: Zóltan Biedermann, Anne Gerritsen, and Giorgio Riello, eds., Global Gifts, the Material Culture of Diplomacy in Early Modern Eurasia (Cambridge: Cambridge University Press, 2017). 
contextualizing globality, materiality, and culture in new ways in reflecting on the impact of transitions and transformations on a global scale, including recycling and different forms of reusability. Globality is therefore rather an acting compound and not a mode of description. This approach separates the epistemological unity of materiality and culture while challenging the notion that connectivity and the permeability of borders are the key concepts of global history. ${ }^{6}$ In this matter, we follow the recent developments in the history of migration, which in the social setting reflects the local changes of migration, but also increasingly raises the question of what forms of social coherence the migration process itself triggers. Going back to our example, the bell, the research context of material culture provides too few opportunities to observe the influence of the global on transition processes. If an object loses the context of its social connotation, why should it keep its attributes on its journey? The same question arises for the material: does a different use of the material point to new assignments of use, appreciation, functions? What do we gain from this? Connecting the travelling of an object with the potential of transformation, there is at least a certain enlargement of the research rationale: The autonomy of the transformation process presumes that culturally connoted objects can be transformed in such a way that they do not arrive at the museum as collectors' items. This leaves us with more possibilities to address gaps, unfulfilled expectations, the potential to ask what is actually missing in museums and whether there could be reasons other than the personal preferences of collectors, the availability of financial resources or supply mechanisms on the art market. During our research, we discovered that Japanese bells are found in large quantities in Swiss collections, while they are rather rare in museums in other countries. ${ }^{7}$ Taking apart the triad of globality, materiality and culture, the history of the Shinagawa bell changes considerably: As presented below, bells which lost their functions in their Japanese environment left the country indeed in considerable numbers, but as part of a flourishing scrap metal trade. Their renaissance as artistic Buddhist bells was a consequence of changed production conditions and the varying demand for bronze. The transformation of the bell to scrap metal leveled out the significant differences between the bells and reconfigured and challenged the analytical framework of material culture. Their renaissance as bells and collector's items followed Western standards, in which the specification of the origin no longer played a significant role, while their significance as artifacts of a global form of historicism increased.

6 As mentioned e.g. by Sebastian Conrad, What is global history? (Princeton: Princeton University Press, 2016), https:// doi.org/10.2307/j.ctvc779r7.

7 For the interest of Swiss collections in Japanese objects see Hans Bjarne Thomsen, "Japanese Collections in Switzerland," in Siebold's Vision of Japan: As Seen in Japan-Related Collections of the West, ed. National Museum of Japanese History (Sakura: National Museum of Japanese History, 2015), 89-98 and 273-280. 


\section{Fire and capitalism}

Given the many uncertainties about the journey the Shinagawa bell has taken since it left Japan, the place where the Geneva art lover bought the bell is remarkably well known. Revilliod bought the bell from the Rüetschi Company, a long-established foundry which had been based in the small Swiss town of Aarau for centuries. In view of the globalized $19^{\text {th }}$ century, it is only moderately surprising that a bell foundry had a Japanese bell to offer. However, focusing on its artistic and cultural significance, the scientific debate about the Shinagawa bell has neglected one surprising fact until now: there was not just one bell in Rüetschi's backyard - there were many.

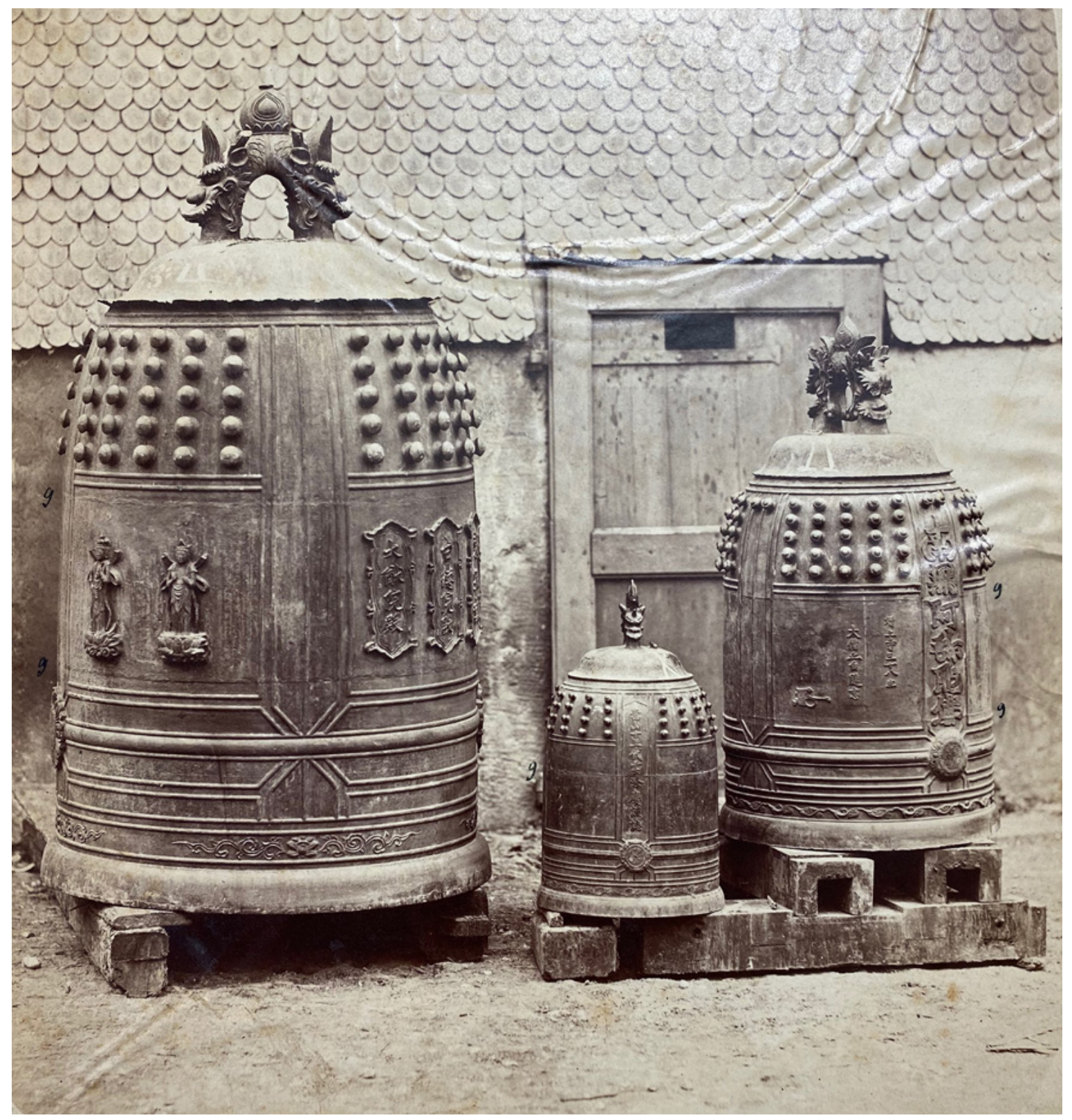

Fig. 1. Of the two versions of the photo presenting Japanese bells in the backyard of the Rüetschi Foundry, one is part of the album of MGCG (see fig. 6 in Hans Bjarne Thomsen's contribution in this issue). Fig. 1 shows another print taken from the same picture, which was added to the Rüetschi company's photo collection. Three Buddhist bells in the backyard of the Rüetschi Foundry. With gratitude to G. Spielmann. Photo: courtesy of H. Rüetschi AG, Aarau. 


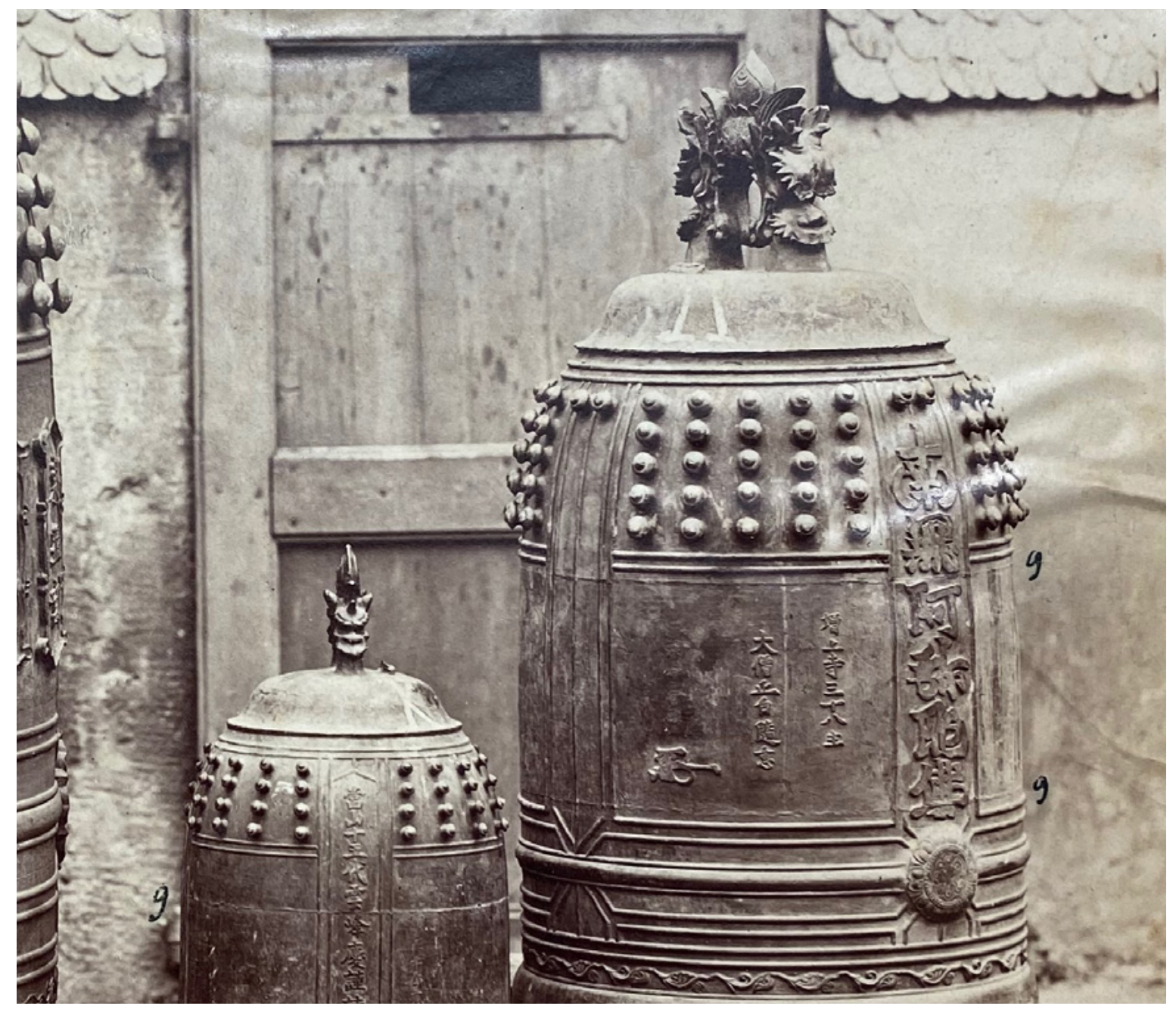

Fig. 2. Roman numerals are visible on the shoulder of the middle and small bells. Enlarged detail of fig. 1.

In the company's picture collection (Fig. 1), a photo taken around 1873 shows three nicely arranged Japanese bells, the largest obviously recognizable as the Shinagawa bell. Interestingly enough, an identical picture is part of a large photo collection, once initiated and owned by the Mittelschweizerische Geographisch-Commercielle Gesellschaft (MGCG). ${ }^{8}$ The MGCG asked their members to send pictures of commercial and ethnographic interest as a matter of course - the association even offered a corresponding membership to those sending pictures. Even though there is no proof that Rüetschi supplied an identical print of the photo to the association, the company is on the list of the MGCG members and donors, and even donated a Japanese temple bell in 1878 to a museum connected to MGCG, as stated below.

8 See fig. 6 in Hans Bjarne Thomsen's contribution in this issue. Hans Bjarne Thomsen, "Japanese Bronze Bells in Switzerland: Global Travel and Local Interpretations," Global Europe - Basel Papers on Europe in a Global Perspective, no. 120 (2021): 13 - 36. 
The MGCG version of the picture classifies the bells incorrectly as Chinese, although comments of unknown origins written by hand as a caption specify the tallest bell as the one Revilliod brought to his estate in Geneva, and whose Japanese origin was well known. But an additional and more general comment on the photograph is even more interesting, explaining the objects in the picture as "very old Chinese bells, a large number of which were melted down in the Rüetschi bell foundry in Aarau." ${ }^{9}$ The "large number" mentioned is somewhat disturbing, but the temporal dimension is even more interesting. Why were "a large number" of bells melted down in the past, but similar objects now neatly arranged in the backyard were obviously spared the same fate? And why did the many apparently melted down bells go unmentioned, while the regional press documented the purchase made by Mr Revilliod, and even announced the arrival of four bells? In January 1873, the Gazette de Lausanne celebrated the imminent arrival of four Japanese bells. They were announced to be melted down, but also described as artistic works, "qui fait le plus grand honneur au génie japonais."

In the following we consider the fact that, rather ironically, the bells appeared in Aarau only to make them disappear, quite literally, by melting them. Does this insight allow us to ask about their origin in a new and different way, involving different 'scales', as a paradigmatic concept in global history? The focus on Japan should help to sharpen our understanding of why the backyard of a Swiss bell foundry ultimately plays a paradigmatic role in better understanding the transformation process of turning sacred Buddhist art into a globally demanded scrap metal and once again into art, although the bells which emerged from this transformation were removed from their original function and newly defined in value by Western collectors.

The photograph from the Rüetschi Company showing three bells is at least in one additional case accurate enough to challenge the findings of the Sinagawa bell with another example, a bell whose inscription assigns the object to the Zōjōji temple. As mentioned by Hans Bjarne Thomsen in his translation of the bell's inscription, the bell was dedicated by the monk Enyo Byakuzui (1656-1730), a high-ranking actor in the temple’s hierarchy. ${ }^{11}$ As the abbot of the Zōjōji temple, Byakuzui was a leading figure in the political bargaining process between the Tokugawa shogunate and the Buddhist temple, which ended up dedicating the temple's political importance as a burial place and memorial for high-ranking members of the Tokugawa dynasty. Relating the

9 "Uralte chin. Glocken, von welchen eine grosse Anzahl in der Glockengiesserei Rüetschi in Aarau eingeschmolzen wurden (ca. 1873)," Anonymous photographer, China, Uralte chinesische Glocken, 1890, Staatsarchiv Aargau, F.MG/2320. 10 “Confédération Suisse. Argovie," Gazette de Lausanne, January 27, 1873, https://www.letempsarchives.ch/page/ GDL_1873_01_27/1.

11 See Thomsen, "Japanese Bronze Bells," 21. 
bell to the abbot for chronological analysis, this intricately decorated bell with extensive inscriptions on its surface was probably made in the 1720s and is therefore younger and less spectacular than the Shinagawa bell. But besides the different age and perhaps artistic value separating the Shinagawa bell from the Zōjōji bell, sometimes mentioned as the Shiba bell, both objects are connected to an astonishingly parallel narrative, at least according to Western literature:

Both were originally situated in quarters with access for foreigners (Shiba) and both were mentioned in Western travelogues. At least as a hypothesis we can state that the decline of the Buddhist temple bells was closely connected with the formation of a global public, all the more since the first foreign legations in Japan were located in Buddhist temples. ${ }^{12}$ Both bells represent the premodern past of Japan in a moment, when a new regime followed the gospel of modernity. In both cases, contemporary narratives assigned a similar fate to the bells, starting with the destruction of their environment. In both cases the respective temple burned down - in the case of the Zōjōji temple even on New Year's Eve $1874 .{ }^{13}$ The narrative tells us that neither political subversion in Japan nor Western looting, just that a major blaze rendered the bells useless. The bells had lost their surrounding temples in the fires and fell out of time in more ways than one. It remains unclear whether the fire was a real event or a metaphorical explanation. In any case, the newspaper report and the dating of the photograph are consistent - but the bell, whose inscription refers to the Shiba Temple, could not have been exposed to the fire. The disaster happened when the bell was already in Aarau. It can be stated that the uselessness of bells was pursued with a considerable discursive effort on a global scale. The metaphorical or real fire destroyed the cultural origin in a moment watches replaced bells as timekeepers. The new era of timekeeping, closely connected to Swiss companies, offers an even better explanation for the disappearance of the temple bells. ${ }^{14}$

The narrative of excessive uselessness obviously helps to justify the transformation of bells into scrap metal - the question is whether we can see any resistance against such a justification, and whether the presumed surplus value taken from the metal value has any historical foundation. The bad news of the burning of the Zojjojji temple indeed circulated globally. Foreigners who had previously visited Shiba's temple because the site was famous for its large bell continued to

12 For the history of the buildings see "History of U.S. Embassy Buildings," American Center Japan, accessed April 26, 2021, https://americancenterjapan.com/aboutusa/usj/4737/. The first American Legation opened in the Gyokusenji Temple, Shimoda, later a consulate was opened in Hongakuji Temple, Yokohama.

13 Theobald A. Purcell, “Our Neighbourhood”; or, Sketches in the Suburbs of Yedo (Yokohama, 1874), 107-113.

14 See Pierre-Yves Donzé, Des Nations, des firmes et des montres. Histoire globale de l'industrie horlogère de 1850 à nos jours (Neuchâtel: Éditions Livreo Alphil, 2020). 
travel to this place even after the disaster. In their travelogues they mentioned that the site had turned into an immense market for Buddhist antiquities..$^{15}$ For methodological reasons however, the link between a disaster and the subsequent exploitation of cultural objects is neither particularly remarkable nor exceptional. In order to gain a solid methodological argumentation, the transformation of bells from a Buddhist work of art to the recycling of scrap metal would have to have left contradictory traces, one related to the scrap metal trade, another which becomes tangible as a critique of capitalism. While the importance of the scrap metal trade brings us back to the backyard of the Rüetschi Company as explained below, traces of the criticism of capitalism connected to the bells arose in Japan. Obviously, in the 1870s, Buddhist monks addressed the now missing bells in complaints to foreign visitors. In this way, the fate of the melted bells reached the literary documentation of a trip around the world, which attracted some attention in the $19^{\text {th }}$ century. Under the title A Voyage in the Sunbeam, Annie Brassey launched a bestseller that has been reprinted no less than 96 times since its first appearance in $1876,{ }^{16}$ and translated into 17 languages. The considerable public attention was related to the book's author, Baroness Annie Brassey (1839-1887), married to a rich heir of British railroad money. Her husband, Sir Thomas Brassey, owned a famous yacht, the Sunbeam, which completed the first circumnavigation of the earth as a steamship of this class in 1876/77. Annie Brassey described in her best-selling travelogue the arrival of the Sunbeam in Japan, and disclosed her specific interest in temple bells within this context. During her visit which included the Nishi-Hongan-ji temple in Kyoto, she started in Gyokusen-ji, a Buddhist temple which served as the first quarters of the US consulate in Japan. Here, she mentions the Buddhist priests' complaints about the declining interest in Buddhism, adding she was told that "speculators are buying up their fine bronze bells, and sending them home to be coined into English pennies and half-pennies." ${ }^{17}$ This rather casual remark electrified a reviewer of the book from missionary circles to some sharp, capitalism-critical remarks. In the Evangelisches Missions Magazin, published in Basel, the reviewer of Brassey's book - then already translated into German - mentioned the bell-trade, but first of all criticized the rich lady's travelogue and the fact she never spoke with missionaries at all. ${ }^{18}$

15 E. R. Hendrix, Around the World, Illustrated ed. (St. Louis, Mo.: L.D. Dameron, 1881), https://catalog.hathitrust.org/Record/100535843. For foreigners, the "owner of the American Legation building" was the best address for such antiquities.

16 “Brassey, Annie, 1839-1887,” WorldCat Identities. http://worldcat.org/identities/lccn-n2002155037/.

17 Annie Brassey, A Voyage in the Yacht "Sunbeam"; Our Home on the Ocean for Eleven Months (Chicago: J.W. Henry, 1880): 318, https://catalog.hathitrust.org/Record/100768343.

18 “Bücherschau. Eine Segelfahrt um die Welt," Evangelisches Missions Magazin. Neue Folge 23 (1879): 440, https://catalog.hathitrust.org/Record/100116874. 


\section{From earmarked bronze to East Asian art?}

Shifting back to Aarau, the bell foundry allows the presumed capitalization of Buddhist temple bells as scrap metal to be examined more closely. As a starting point, a technical note from Rüetschi is important in assessing the cost issue: the transport of scrap metal exceeds the dimensions normal cargo. Empty ships or those with lightweight cargo need ballast; temple bells, especially the large ones such as the Shinagawa bell have an almost ideal format for ballast loading. ${ }^{19}$ Therefore the question of transport costs is probably not the decisive problem, although the opening of the Suez Canal in 1869 shortened the long journey considerably. Leaving aside the probably interesting question concerning the extent to which ballast should be an issue in a tripartite research strategy on globality, materiality, and culture, in light of the relative transport costs the quality of the material is indeed an important question. Japanese bells had an excellent reputation because antique bronze (that is to say bronze produced before the Meiji period) was of a particularly high quality compared to Western production. Published in The Japan Weekly Mail in 1880, an article about Japanese metalwork highlighted with reference to the Shiba bell the specific characteristics of Japanese bronze, pointing out that the exceptionally pure sound of the temple bell resulted from mixing the bronze with gold and silver according to a recipe not known in Europe. ${ }^{20}$ Western literature was aware of the sophisticated specificities of Japanese metal alloys, and the quality of Japanese bronze works was mentioned in almost every Western encyclopedia. ${ }^{21}$ In Western metallurgical and chemical literature published in the $19^{\text {th }}$ century, the admiration for old Japanese bronze is evident as well; typically, the high quality of Japanese alloy and metal processing, coloring, and the precision of workmanship are mentioned - regardless of whether the object is a sword, a mirror, or a richly decorated temple bell. If especially old bells had a high metal value and the temples were ready to sell bronze from the remains of a fire catastrophe, and if such objects indeed became part of a global scrap metal trade, how can we demonstrate that materiality has detached itself from the cultural connotation of the bell? The question first requires the abandonment of the idea that the temple bells are unique works of art whose winding paths can be traced more or less well, as in the example of the Shinagawa bell.

Instead, we will pursue the question of whether their transformation from bells to scrap metal can be traced as a result of their worldwide journey. In fact, the search for similar bells in Swiss collections shows a fascinating similarity. In the photograph from the Rüetschi collection, signs engraved on the shoulder of the bells are visible. Reference examples in the Museum der

19 Many thanks to Mr Spielmann, H. Rüetschi AG, Aarau, for this information.

20 “Japanese metalwork," The Japan Weekly Mail, March 20, 1880.

21 Meyers Grosses Konversations-Lexikon even had an article about the city of Kanazāwa, famous for its bronze production, see "Kanazāwa," in Meyers Großes Konversations-Lexikon, vol. 10, $6^{\text {th }}$ ed (Leipzig/Vienna: Bibliographisches Institut, 1907), 555, http://www.zeno.org/Meyers-1905/K/meyers-1905-010-0555. 
Kulturen, Basel, show similar signs. Three bells of different, although Japanese origin bear the same markings, consisting of Roman numerals on one hand, and the Japanese character for "good quality," as discovered by Hans Bjarne Thomsen..$^{22}$ As a working hypothesis, we are currently assuming that the brands in question were those which concerned the quality of bronze and prepared the objects for transport. The signs clearly have nothing to do with a bell used in any way, but defined the objects in new ways.

Since the Roman numerals have even been stamped over the original inscriptions on the bell in an almost rude way, the question arises again: why do these 'things' become collectibles? The separation of materiality and culture, for example the detachment of social connotation from the object and a re-evaluation of its materiality, at least opens up some new assumptions: here we once again follow the trail of the World's Fairs. This time, however, we do not expect to find that Japanese temple bells were exhibited. Although no Buddhist bells are mentioned, neither for the exhibition in Paris in 1867 nor in Vienna in 1873 despite Japanese participation, the reports and catalogues present valuable information about a crucial shift in the use of the material the bells were made of - bronze. We can note that the Western century of historicism was expressed in an increasing demand for monuments. The urban construction boom, which catapulted cities like Paris from the Middle Ages to the Paris of the boulevards, left their traces in the metalworking industry. Rüetschi not only cast the first equestrian statue in Switzerland, the company also participated in the decoration of the Swiss Federal building. Rüetschi moved slowly away from the centuries-old tradition of transforming bronze from bells into cannons and established an increasing reputation in the production of monuments. The world exhibitions show that the hunger for monuments has been increasingly satisfied with cheaper materials. The reports of the Paris industrial exhibition of 1867 celebrated art casting as a new method for material processing. Art casting allowed the production of opulently decorated large objects, suitable for public spaces - for example as candelabras for gas lighting - but also ideal for balcony grilles and interior decoration of houses in the now dominant style of historicism. Based on iron, art casting started replacing the expensive production of bronze, still present but decreasing in its importance. ${ }^{23}$

The Rüetschi Company almost certainly sent someone to the large international industrial exhibitions, which increasingly became platforms of global competition for industrial products. It will therefore not have gone unnoticed by visitors from Aarau that historicism increased the

22 See Thomsen, “Japanese Bronze Bells,” 20.

23 Illustrirter Katalog der Pariser Industrie-Ausstellung von 1867 (Leipzig: F. A. Brockhaus, 1868), 275 ,

https://doi.org/10.11588/diglit.1331\#0283. 
demand for monuments made of metal alloys to a degree that exceeded the demand for bells by far. In addition, the Rüetschi Company had other reasons to expand their production, due to a substantial change in the weapons industry. As was common for bell foundries of the time, Rüetschi manufactured both, bells and cannons. In the second half of the 19th century, however, the centuries-old procedure of recasting bells into cannons underwent a significant change due to a shift in technology, ultimately ending the old practice. From the middle of the century until the 1860s, the modification of gun barrels provided the company with increasing orders, which consisted in re-casting the existing bronze barrels. Ten years later, however, the German company Krupp had developed cast steel cannons, which were clearly superior to the bronze cannons. ${ }^{24}$ In Switzerland, the re-equipment of the army relied on newer guns with iron barrels starting in the 1860s and continuing in the 1870s with the purchase of guns from Krupp. Even if bronze did not disappear completely from weapons production, the process of melting down bells was no longer a promising business model - parallel activities in casting works of art certainly made it seem wise to transform the now useless Japanese bronze back into works of art.

\section{"Exploratio Mundi Liberat Animum:" education based on global trade}

The transformation from scrap metal to a work of art requires a cultural concept, which in our example was characterized, supported and performed by an association typical for the period of imperialism and colonial expansion, the Mittelschweizerische Geographisch-Commercielle Gesellschaft (MGCG), mentioned above. At second glance, the MGCG had a specific global aim and profile. Although it was a rather short-lived association, founded in 1884 and dissolved in 1905, the MGCG expanded its activities substantially, made its collections available to the public and published its own journal. The journal's front page is decorated with the Latin logo "Exploratio Mundi Liberat Animum" and shows in golden imprints a premodern ship sailing towards the East. The title of the journal, Fernschau (distant viewing), ${ }^{25}$ presented the specific global openness of an association located in a small Swiss commercial town in unusually systematic and remarkable ways. The association brought together almost every business involved in export, from the established silk ribbon industry to the bell foundry, from scholars to traders, and - what is

24 Verena Naegele, “Ein Traditionsunternehmen mit vielen Facetten: Die Glocken- und Kunstgiesserei Rüetschi,” Aarauer Neujahrsblätter 83 (2009): 110 -129, http://doi.org/10.5169/seals-559215.

25 Fernschau. Jahrbuch der Mittelschweizerischen Geographischen-Commerciellen Gesellschaft in Aarau (Aarau: H. R. Sauerländer, 1886-1894), https://kbaargau.visual-library.de/periodical/pageview/3187. 
even more remarkable - covering a space across cantons, where the well-known Swiss hubs of global trade were explicitly left out. Instead of Basel, Zurich and Geneva, the membership linked Aarau, Basel-Land, Lucerne and Solothurn. The concept of the commercial museum combined the goal of broad education of the population with the requirements of the global market - objects from distant countries served as illustrative material and at the same time were intended to ensure global expertise in the expanding export industry. Members of associations attached to such educational aims crossed the boundaries between trade, science and industry. In the understanding of MGCG, a corresponding member gained this title by delivering photographs and/ or objects, independent of whether they were located in the neighboring village or in East Asia. ${ }^{26}$

The connection between the bells and the MGCG seems obvious - but no clear provenance can be deduced for the bells, due to the large gaps in the documentation. The missing links result from seemingly plausible facts: the MGCG had large holdings but a short life span, so the collected objects were divided up and merged into different collections. Since the dissolution of the MGCG occurred during the lifetime of one generation, donors could also have withdrawn their gifts after the dissolution of the association. ${ }^{27}$ Although the Basel Museum der Kulturen took over at least some parts of the MGCG collection, the acquisition occurred more than ten years after the association was dissolved. The respective correspondence in the museum's files documents the transfer of the objects to different institutions, with the cantonal Commercial Museum of Aarau (Gewerbemuseum) being their first destination. In December 1917 this Gewerbemuseum offered the non-European objects of the former MGCG to the Basel Museum for sale. ${ }^{28}$ Johann Ludwig Meyer-Zschokke, who as founding director of the Gewerbemuseum was still in charge at the time, explained the history of the collection offered for sale in a letter dated February 11, 1918 to the Basel Museum Commission. ${ }^{29}$

The letter's main message was that no catalogue, invoices, receipts, or purchase books had been preserved. At this point, historical provenance research would come to an end, with only the assumptions offered by Meyer-Zschokke as an explanation. With an approach that considers globality, materiality and culture as intertwined but occupying different levels of action,

26 Mitgliederverzeichnis, ibid., XIVff. As corresponding members in Japan were mentioned: Wilh. (Wilfried) Spinner, Tokio, Donators: F. Wagen Frères, Yokohama.

27 Two of the three bells, IId 914 and IId 1767, from the holdings of the Museum der Kulturen were acquired indirectly through inheritance and as deposits. Many thanks to Alia Özvegy from Museum der Kulturen for helping us with the provenience of the bells.

28 The reason was restricted space and expansion plans. See Staatsarchiv Aargau, ZwA 2007.0042, Kantonales Gewerbemuseum mit Gewerbeschule, 1868 -1961 (Bestand), https://www.ag.ch/staatsarchiv/suche/detail.aspx?ID=1634.

29 Museum der Kulturen Basel, Dokumentenarchiv 05-0037-ID 865. 
Meyer-Zschokke's explanations are more than an educated guess. Beyond all expected facts, the Meyer-Zschokke's narrative explains why the bells constantly escape a research approach which understands the bells as collectors' items. In Meyer-Zschokke's narrative, the MGCG was less an institution than a living organism, a community in which travelling Swiss nationals connected with the broad community of expats and Swiss traders working outside Europe. Groups with diverse social and local backgrounds communicated with each other through real objects and photographed items. Both objects and images refer to this social context. The activity of collecting creates far more than a contemplation of the world through an exhibition. Rather, we see that a Swiss society, formed across cantonal borders, makes a contribution to the global, thus legitimizing itself as a global actor. This approach overstepped institutional boundaries in many ways. While the MGCG was the initiator and holder of the bells' photograph in the Rüetschi backyard, a Japanese bell donated by Rüetschi is mentioned in the catalogue of the Argovian Antiquarium, a collection in which some of the MGCG objects were integrated. ${ }^{30}$ Among the objects added in 1878 to the Antiquarium collection was a bronze representing a mythological animal described as "tempest dragon" (Sturmdrachen) - and a temple bell, both from Japan and both provided by Emanuel Rüetschi, the owner of the bell foundry. ${ }^{31}$ In both cases the objects share the same materiality, a fact mentioned in the museum catalogue. ${ }^{32}$ When Meyer-Zschokke wrote his letter to the Basel museum as the director of the still existing Aarauer Gewerbemuseum, he represented an institution composed of the remains of various collections. Their intentions, contexts and aims were far apart from each other, but the analytical patterns of globality, materiality and culture are still clearly visible: many years after the MGCG had disappeared, the association's global approach remained of importance. In his short outline of the collection history, MeyerZschokke even brought in one of our usual suspects, the World Fairs: a number of objects owned by MGCG allegedly came from the holdings of world exhibitions. This assumption does not lead to the location of further objects, but allows insights into the communication networks, established and used by the charismatic secretary of MGCG, Karl Wilhelm Bührer (1861-1917). Bührer is better known as the initiator of standardized advertising cards and of the Internationale Monogesellschaft. ${ }^{33}$ However, Meyer-Zschokke's somehow mysterious reference to the World

30 Later the Antiquarium was merged with the Aarau Gewerbemuseum. Inventar, ibid.

31 Historische Gesellschaft des Kantons Aargau, "Vereinschronik," Argovia: Jahresschrift der Historischen Gesellschaft des Kantons Aargau 10 (1879): IX. https://catalog.hathitrust.org/Record/000520176. For the dragon see Madeleine Herren, “Ein 'Sturmdrache' im globalen Bronzehandel," in Materialized Histories. Eine Festschrift 2.0, eds. Tina Asmussen, Eva Brugger, Maike Christadler, Anja Rathmann-Lutz, Anna Reimann, Carla Roth, Sarah-Maria Schober, Ina Serif (15/07/2021), https://mhistories.hypotheses.org/?p=4249.

32 E.L. Rochholz, Katalog des Kantonalen Antiquariums in Aarau (Aarau, 1879), $40 f$.

33 The Swiss National Library has archived examples of such advertising cards by the Monogesellschaft. Helvetic Archives, Archivdatenbank der Schweizerischen Nationalbibliothek. GS-Mono, Internationale Mono-Gesellschaft: Mono-Ansichten, 1922 G. 3895; K-12 G 40, accessed April 26, 2021, https://www.helveticarchives.ch/detail.aspx?ID=628119. 
Fairs indirectly unveils Bührer's close contacts to Justus Brinkmann in Hamburg, the founding director of the Museum für Kunst und Gewerbe (MKG). Opened in 1874 and following the respective examples in Kensington and Vienna, the MKG was the very example and model of the Swiss intentions. Brinkmann did indeed buy the first MKG holdings from the collections of the world exhibitions. From the very beginning, the huge Hamburg museum had an East Asian collection focusing on Japan. ${ }^{34}$ But even more importantly, the MKG provided a visible, sustainable and consistent implementation of a concept of culture in which the promotion of a global export industry required the introduction of a training course on global objects.

\section{Conclusions}

It may seem unfortunate if the storm dragon and the bell survive merely because they are both made of a certain alloy. However, this disillusioning observation also opens up new possibilities for search strategies and research questions. Thus, the separation of materiality and cultural connotation has led to the insight that Switzerland became a collection point for ancient Japanese bells, which are quite rarely found in the collections of other Western states. The complex transformation of things into scrap metal and its reassessment as teaching pieces for the educational reasons a Gewerbemuseum was based on, allows us to test different assumptions and questions. Is a bell designated as scrap metal still a bell fitting for a museum collection? Are such objects helpful as a challenge to established collections and museum histories? Does the chaotic migration of bells through the institutions point to a different 'life of things', where the process of collecting oversteps the institutional rationale? At least, we may consider new research strategies: objects rejected by museums, or loans remaining in legal limbo for years, or pieces devalued by transport stamps are possibly suitable for opening up a corner of global history that has so far been ignored.

34 “Permanent Collection: East Asia," Museum für Kunst und Gewerbe Hamburg, accessed April 26, 2021, https://www. mkg-hamburg.de/en/collection/permanent-collection/east-asia.html. 


\section{Bibliography}

American Center Japan. "History of U.S. Embassy Buildings.” Accessed April 26, 2021. https:/| americancenterjapan.com/aboutusa/usj/4737/.

Ariana Musée Suisse de la Céramique et du Verre. “The Park.” Accessed April 26, 2021. http://institutions.ville-geneve.ch/en/ariana/discover/history/the-park/.

Association d'amitié Genève-Shinagawa. “Historique de La Cloche.” Accessed April 26, 2021. http:// www.geneve-shinagawa.ch/cloche.html.

Berg, Maxine et. al. eds. Goods from the East, 1600-1800. Trading Eurasia. London: Palgrave Macmillan, 2015.

Biedermann, Zoltán, Anne Gerritsen, and Giorgio Riello, eds. Global Gifts: The Material Culture of Diplomacy in Early Modern Eurasia. Cambridge: Cambridge University Press, 2017.

Brassey, Annie. A Voyage in the Yacht "Sunbeam:" Our Home on the Ocean for Eleven Months. Chicago: J. W. Henry, 1880. https://babel.hathitrust.org/cgi/pt?id=coo1.ark:/13960/ t6640b610\&view=1up\&seq=13.

“Brassey, Annie, 1839-1887” WorldCat Identities. Accessed April 26, 2021. http://worldcat.org/ identities/lccn-n2002155037/.

“Confédération Suisse. Argovie.” Gazette de Lausanne, January 27, 1873. https://www.letempsarchives.ch/page/GDL_1873_01_27/1.

Conrad, Sebastian. What Is Global History? Princeton: Princeton University Press, 2016.

Contel, Raphael, Anne Laure Bandle, and Marc-André Renold. "Affaire Cloche de Shinagawa Ville de Genève et Temple de Shinagawa." Plateforme ArThemis (http://unige.ch/art-adr). Centre du droit de l'art, Université de Genève. Accessed April 26, 2021. https://plone.unige. ch/art-adr/cases-affaires/cloche-de-shinagawa-2013-ville-de-geneve-et-japon.

Donzé, Pierre-Yves. Des Nations, des firmes et des montres. Histoire globale de l'industrie horlogère de 1850 à nos jours. Neuchâtel: Éditions Livreo Alphil, 2020.

“Eine Segelfahrt um die Welt.” Evangelisches Missions Magazin. Neue Folge 23 (1879): 440. https:// catalog.hathitrust.org/Record/100116874.

F.C. “Cloche japonaise de l'Ariana." Bulletin de La Société Franco-Japonaise de Paris 71 (1930): 108 -109. https://gallica.bnf.fr/ark:/12148/bpt6k9682009t.texteImage.

Fernschau. Jahrbuch der Mittelschweizerischen Geographischen-Commerciellen Gesellschaft in Aarau. Aarau: H. R. Sauerländer, 1886-1894. https://kbaargau.visual-library.de/periodical/ pageview/3187.

Gerritsen, Anne and Giorgio Riello, eds. Writing Material Culture History, $2^{\text {nd }}$ ed. London et. al.: Bloomsbury Academic, 2021.

Gerritsen, Anne and Giorgio Riello, eds. The Global Lives of Things. The Material Culture of Connections in the Early Modern World. London/New York: Routledge, 2016. 
Grange, Didier. "Quand l'histoire rencontre la légende." In Genève-Shinagawa Shinagawa-Genève, ed. Eric Burkhard et al., 31-40. Geneva: Association d'amitié Genève-Shinagawa, 1996.

Helvetic Archives, Archivdatenbank der Schweizerischen Nationalbibliothek. GS-Mono. Internationale Mono-Gesellschaft: Mono-Ansichten. 1922 G. 3895; K-12 G 40. Accessed April 26, 2021. https://www.helveticarchives.ch/detail.aspx?ID=628119.

Hendrix, Eugene R. Around the World. Illustrated ed. St. Louis, Mo.: L.D. Dameron, 1881. https:// catalog.hathitrust.org/Record/100535843.

Herren, Madeleine. “Ein ‘Sturmdrache' im globalen Bronzehandel.” In Materialized Histories. Eine Festschrift 2.0, edited by Tina Asmussen, Eva Brugger, Maike Christadler, Anja RathmannLutz, Anna Reimann, Carla Roth, Sarah-Maria Schober, Ina Serif. 15/07/2021. https://mhistories. hypotheses.org/?p=4249.

Historische Gesellschaft des Kantons Aargau. "Vereinschronik." Argovia: Jahresschrift der Historischen Gesellschaft des Kantons Aargau 10 (1879): VII - XIX. https://catalog.hathitrust. org/Record/000520176.

Illustrierter Katalog Der Pariser-Industrie-Ausstellung von 1867. Leipzig: F.A. Brockhaus, 1868. https://doi.org/10.11588/diglit.1331\#0283.

JACAR (Japan Center for Asian Historical Records). Ref. B04012326800. Miscellaneous Documents Relating to Antiques and Treasures/ 8. Documents Relating to Great Bell of Buddhist Temple at Musee Ariana in Geneva. (I-1-7-0-8) (Diplomatic Archives of the Ministry of Foreign Affairs). Accessed April 26, 2021. www.jacar.archives.go.jp.

“Japanese Metal-Work." The Japan Weekly Mail, March 20, 1880.

“Kanazāwa." In Meyers Großes Konversations-Lexikon, vol. 10, $6^{\text {th }}$ ed., 555. Leipzig/Vienna: Bibliographisches Institut, 1907. http://www.zeno.org/Meyers-1905/K/meyers-1905-010-0555.

Museum der Kulturen Basel, Dokumentenarchiv 05-0037-ID 865.

Museum für Kunst und Gewerbe Hamburg. "Permanent Collection: East Asia." Accessed April 23, 2021. https://www.mkg-hamburg.de/de/.

Naegele, Verena. "Ein Traditionsunternehmen mit vielen Facetten: Die Glocken- und Kunstgiesserei Rüetschi.” Aarauer Neujahrsblätter 83 (2009): 110 - 129. http://doi.org/10.5169/ seals-559215.

Purcell, Theobald Andrew. “Our Neighbourhood”; or, Sketches in the Suburbs of Yedo. Yokohama, 1874. Rochholz, E.L., Katalog des Kantonalen Antiquariums in Aarau, Aarau 1879. 
Staatsarchiv Aargau. ZwA 2007.0042. Kantonales Gewerbemuseum mit Gewerbeschule, 1868-1961

(Bestand). Accessed April 26, 2021. https://www.ag.ch/staatsarchiv/suche/detail.aspx?ID=1634.

Thomsen, Hans Bjarne. "Japanese Bronze Bells in Switzerland: Global Travel and Local Interpretations." Global Europe - Basel Papers on Europe in a Global Perspective, no. 120 (2021): 13-36.

Thomsen, Hans Bjarne. “Japanese Collections in Switzerland.” In Siebold's Vision of Japan: As Seen in Japan-Related Collections of the West, edited by The National Museum of Japanese History, 89-98 and 273-80. Sakura: National Museum of Japanese History, 2015. 